\title{
Influence of fructose feeding on individual enzymic reactions in the formation and metabolism of bile acids in rat liver homogenates
}

\author{
BY M. CARRELLA, I. BJÖRKHEM, K. EINARSSON \\ AND K. HELLSTRÖM \\ Department of Medicine, Serafimerlasarettet and Department \\ of Chemistry, Karolinska Institutet, Stockholm, Sweden
}

(Received 8 December 1975 - Accepted 23 February 1976)

\begin{abstract}
r. Rats were maintained for $10 \mathrm{~d}$ on a semi-synthetic diet containing $700 \mathrm{~g}$ glucose or $700 \mathrm{~g}$ fructose $/ \mathrm{kg}$. Individual enzymic reactions in bile acid synthesis and metabolism were studied by measuring the $7 \alpha$-hydroxylation of $\left[4^{14} \mathrm{C}\right]$ cholesterol, the $12 \alpha$-hydroxylation

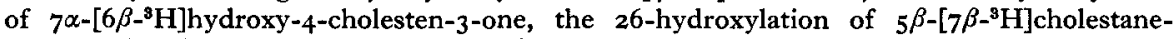
$3 \alpha, 7 \alpha$-diol and the $6 \beta$-hydroxylation of $\left[{ }^{3} \mathrm{H}\right]$ lithocholic acid in liver homogenates.

2. The serum cholesterol level was approximately the same in both groups of animals, but the serum triglyceride level was almost twice as high in the fructose-fed rats compared to the glucose-fed rats.

3. The $6 \beta$-hydroxylation of $\left[{ }^{3} \mathrm{H}\right]$ lithocholic acid was increased by about $20 \%$ in the fructose-fed rats compared to the glucose-fed animals. The activities of the other enzymic reactions studied did not differ significantly between the two groups of animals. The findings are discussed in relation to previous knowledge concerning mechanisms regulating triglyceride, pre- $\beta$-lipoprotein and bile acid synthesis.
\end{abstract}

The ingestion of diets rich in carbohydrates results in increased concentration of serum triglycerides and pre- $\beta$-lipoproteins in man (cf. Kaufmann \& Kapitulnik, 1973) as well as in rats (Nikkilä \& Ojala, 1965; Eaton \& Kipnis, 1969; Schonfeld \& Pfleger, 197I). These effects are generated with unequal efficacy by different carbohydrates. Sucrose and fructose have proved to be more potent than starch and glucose (Anderson, Grande, Matsumoto \& Keys, r963; Macdonald \& Braithwaite, 1964; Nikkilä \& Ojala, I965; Waddell \& Fallon, 1973). The carbohydrate-induced hyperlipidaemia has been found to be associated with an enhanced formation of and secretion of lipoproteins from the liver in both man (Quarfordt, Frank, Shames, Berman \& Steinberg, 1970; Wu \& Shreeve, 1975) and rat (Eaton \& Kipnis, 1969; Waddell \& Fallon, 1973).

Hyperlipoproteinaemia type IV is characterized by hyperpre- $\beta$-lipoproteinaemia (Frederickson, Levy \& Lees, 1967), an increased production of plasma triglycerides (Reaven, Hill, Gross \& Farquhar, I965; Nestel, I966; Nikkilä \& Kekki, I972; Adams, Kissebah, Harrigan, Stokes \& Wynn, 1974) and an abnormally high formation of bile acids (cf. Einarsson, Hellström \& Kallner, 1974). The latter effect is pronounced for cholic acid whereas the synthesis of chenodeoxycholic acid is almost within normal limits (Einarsson et al. 1974).

The various factors regulating bile acid production are not all known. The possibility that an abnormal formation of very-low-density lipoproteins (VLDL) is associated with an enhanced bile acid synthesis initiated the present study. Rats were given 
either a glucose-rich or a fructose-rich diet, the latter a regimen known to result in hyperpre- $\beta$-lipoproteinaemia. Several enzymic reactions involved in the biosynthesis and metabolism of bile acids were studied in liver homogenates.

\section{EXPERIMENTAL PROCEDURES}

\section{Materials}

$\left[4^{-14} \mathrm{C}\right]$ cholesterol ( $145 \mu \mathrm{Ci} / \mathrm{mg}$ ) was obtained from the Radiochemical Centre (Amersham, Bucks., UK). Before it was used, it was purified by chromatography on a column of aluminium oxide (grade III; Woelm, Eschwege, Germany). $7 \alpha$ $\left[6 \beta-{ }^{3} \mathrm{H}\right]$ hydroxy-4-cholesten-3-one $(6 \cdot 7 \mu \mathrm{Ci} / \mathrm{mg})$ was prepared according to Björkhem (1969) and $5 \beta-\left[7 \beta-{ }^{3} \mathrm{H}\right]$ cholestane- $3 \alpha, 7 \alpha$-diol $(16 \cdot 7 \mu \mathrm{Ci} / \mathrm{mg})$ was synthesized as described by Björkhem \& Gustafsson (1973). $\left[{ }^{3} \mathrm{H}\right]$ lithocholic acid (го $\mu \mathrm{Ci} / \mathrm{mg}$ ) was purchased from New England Nuclear Corporation, Boston, Mass., USA. The purity of the isotopes was tested by thin-layer chromatography (TLC).

NADP, NADPH, isocitric acid and isocitric acid dehydrogenase (EC I.I.I.4I) were obtained from Sigma Chemical Co., St Louis, Mo., USA. Casein was manufactured by E. Merck AG, Darmstadt, Germany. Vitamins (vitamin diet-fortification mixture) and salts (Hawk Oser salt mixture no. 3) were purchased from Nutritional Biochemicals Corp., Cleveland, Ohio, USA.

\section{Animals}

White male rats of the Sprague-Dawley strain, weighing about $\mathrm{I} 5^{\circ} \mathrm{g}$, were used. Twelve rats were given a semi-synthetic diet of $(\mathrm{g} / \mathrm{kg})$ glucose 700 , casein 180 , maize oil 50 , vitamins 20 and salts 50 , and twelve other rats were given the same diet except that glucose was replaced by fructose. The rats were given these diets and water ad lib. for to d. After fasting overnight, six rats in each group were anaesthetized with ethyl ether and blood was drawn from the abdominal aorta for determination of cholesterol and triglycerides. The remaining rats were killed by a blow on the neck. The liver was excised immediately and chilled on ice.

\section{Preparation of liver homogenates}

Liver homogenates $(0 \cdot 2: \mathrm{I}, \mathrm{w} / \mathrm{v})$ were prepared in a modified $0 \cdot \mathrm{I} \mathrm{M}$-Bucher medium (Bergström \& Gloor, I955), $\mathrm{pH} 7 \cdot 4$, using a Potter-Elvehjem homogenizer equipped with a loosely fitting pestle. A portion of the homogenate was refluxed for $\mathrm{I} h$ with 5 vol. chloroform-methanol $(\mathrm{I}: \mathrm{I}, \mathrm{v} / \mathrm{v})$ and the organic extract was analysed for cholesterol and triglycerides. The remainder of the homogenate was centrifuged at $20000 \mathrm{~g}$ for $\mathrm{I}_{5} \mathrm{~min}$ and the supernatant fluid fraction was analysed for cholesterol and protein. The microsomal fraction was obtained by centrifuging the $20000 \mathrm{~g}$ supernatant fluid fraction at $100000 \mathrm{~g}$ for $70 \mathrm{~min}$. Having been suspended in the homogenizing medium, the microsomal fraction was homogenized with a loosely fitting pestle and analysed for protein.

Protein, cholesterol and triglycerides were determined according to the methods of Lowry, Rosebrough, Farr \& Randall (195I), Hanel \& Dam (1955) and Laurell (1966) respectively. 


\section{Incubations}

Labelled cholesterol, $7 \alpha$-hydroxy-4-cholesten-3-one, $5 \beta$-cholestane-3 $\alpha, 7 \alpha$-diol and lithocholic acid were incubated with various fractions of the liver homogenates. $\Lambda$ fter extraction with organic solvents, the radioactive compounds were separated by TLC. The area of silica gel corresponding to each of the various compounds was removed separately and analysed for radioactivity. Incubation procedures and methods for the identification of the various metabolites formed were as follows.

Cholesterol. $\left[4^{-14} \mathrm{C}\right]$ cholesterol, $\mathrm{I} 3 \mu \mathrm{g}$ in $50 \mu \mathrm{l}$ acetone, was incubated for $20 \mathrm{~min}$ at $37^{\circ}$ with $3 \mathrm{ml} 20000 \mathrm{~g}$ supernatant fluid fraction. The incubations were stopped by the addition of $20 \mathrm{vol}$. chloroform-methanol $(2: \mathrm{I}, \mathrm{v} / \mathrm{v})$. The chloroform extract was fractionated as described by Danielsson, Einarsson \& Johansson (1967).

$7 \alpha$-Hydroxy-4-cholesten-3-one. $7 \alpha-\left[6 \beta-{ }^{3} \mathrm{H}\right]$ hydroxy-4-cholesten-3-one, $50 \mu \mathrm{g}$ in 5o $\mu \mathrm{l}$ acetone, was added to a mixture of $2 \mathrm{ml}$ microsomal fraction and $\mathrm{I} \mathrm{ml}$ Bucher medium containing $3 \mu \mathrm{mol} \mathrm{NADPH}$. The incubations were carried out for $10 \mathrm{~min}$ at $37^{\circ}$ and the reaction stopped as described above. The labelled material was analysed as described previously (Björkhem \& Einarsson, 1970).

$5 \beta$-Cholestane- $3 \alpha, 7 \alpha$-diol. $5 \beta$ - $\left[7 \beta_{-3}{ }^{3} \mathrm{H}\right]$ cholestane- $3 \alpha, 7 \alpha$-diol, $25^{\circ} \mu \mathrm{g}$ in $50 \mu \mathrm{l}$ acetone, was incubated for 20 min at $37^{\circ}$ in a mixture of $1.5 \mathrm{ml}$ microsomal fraction, $1.5 \mathrm{ml}$ Bucher medium and a NADPH-generating system consisting of $0.03 \mu \mathrm{mol}$ manganese chloride, $3 \mu \mathrm{mol} \mathrm{NADP}, 12.5 \mu \mathrm{mol}$ isocitrate and $10 \mu \mathrm{l}$ isocitric acid dehydrogenase solution. The reaction was stopped as described previously. Analyses of radioactive substances were done according to Björkhem \& Gustafsson (1973).

Lithocholic acid. $\left[{ }^{3} \mathrm{H}\right] \mathrm{lithocholic}$ acid, $50 \mu \mathrm{g}$ in $5^{\circ} \mu \mathrm{l}$ aqueous ethanol (95:100, $\mathrm{v} / \mathrm{v}$ ), was added to $\mathrm{r} \mathrm{ml}$ microsomal fraction and $2 \mathrm{ml}$ Bucher medium containing $3 \mu \mathrm{mol} \mathrm{NADPH}$. The incubations were carried out for $20 \mathrm{~min}$ at $37^{\circ}$ and stopped by the addition of ethanol $(3 \mathrm{ml})$. Further analysis of the ethanol extract was done as described previously (Einarsson \& Gustafsson, 1974).

\section{RESULTS}

The mean $( \pm \mathrm{SE})$ concentrations of cholesterol in serum were $2 \cdot 10 \pm 0.29$ and $2 \cdot 20 \pm 0 \cdot 16 \mathrm{mmol} / \mathrm{l}$ for animals given diets containing glucose and fructose respectively. Corresponding values for serum triglycerides were $530 \pm \mathrm{r} 30$ and $960 \pm 60 \mathrm{mg} / \mathrm{l}$ respectively, and this difference was highly significant $(P<0.005)$.

As compared to rats given glucose, those given fructose had heavier livers, which had higher cholesterol contents. The triglyceride content tended to be higher in fructose-fed rats but it did not differ significantly from that of rats given glucose. The levels of cholesterol and protein in the $20000 \mathrm{~g}$ supernatant fluid fraction, and the concentration of protein in the microsomal fraction was almost the same in the two groups of animals (Table $\mathbf{I}$ ).

Incubations with $\left[4^{-14} \mathrm{C}\right]$ cholesterol. The pattern of cholesterol metabolites was the same in the two groups. The metabolites formed enzymically under the present conditions were identified previously as 5 -cholestene- $3 \beta, 7 \alpha$-diol, $7 \alpha$-hydroxy-4- 
Table I. Body-weight, liver weight and concentrations of lipids and protein in the liver of rats fed on a semi-synthetic diet containing either glucose or fructose*

(Mean values with their standard errors for six rats/group)

\begin{tabular}{|c|c|c|c|c|c|}
\hline & \multicolumn{2}{|c|}{ Glucose diet } & \multicolumn{2}{|c|}{ Fructose diet } & \multirow{2}{*}{$\begin{array}{c}\text { Statistical } \\
\text { significance of } \\
\text { difference betwe } \\
\text { means }\end{array}$} \\
\hline & Mean & SE & Mean & $\mathbf{S E}$ & \\
\hline Body-wt (g) & 204 & 5 & 205 & 4 & NS \\
\hline Liver wt (g/kg rat) & $4 \cdot 5$ & 0.1 & $5 \cdot I$ & 0.2 & $P<0.01$ \\
\hline $\begin{array}{l}\text { Liver triglycerides } \\
(\mathrm{mg} / \mathrm{g})\end{array}$ & $9 \cdot 0$ & 0.3 & $\mathrm{II} \cdot 4$ & $I \cdot 9$ & NS \\
\hline $\begin{array}{l}\text { Liver cholesterol } \\
(\mu \mathrm{mol} / \mathrm{g})\end{array}$ & $67 \cdot 3$ & $2 \cdot 6$ & $85 \cdot 5$ & $7 \cdot 7$ & $P<0.005$ \\
\hline $\begin{array}{l}\text { Cholesterol concen- } \\
\text { tration of } 20000 \mathrm{~g} \\
\text { supernatant fluid } \\
\text { fraction } \uparrow(\mu \mathrm{mol} / \mathrm{ml})\end{array}$ & $5 \cdot 2$ & 0.5 & $5 \% 7$ & 0.5 & NS \\
\hline $\begin{array}{l}\text { Protein concentration } \\
\text { of } 20000 \mathrm{~g} \text { super- } \\
\text { natant fluid fraction } \dagger\end{array}$ & $18 \cdot 2$ & 0.1 & $17 \cdot 8$ & 0.3 & NS \\
\hline \multirow[t]{2}{*}{$\begin{array}{l}\text { Protein concentration } \\
\text { of the microsomal } \\
\text { fraction } \dagger(\mathrm{mg} / \mathrm{ml})\end{array}$} & $2 \cdot 4$ & O.I & $2 \cdot 2$ & O.I & NS \\
\hline & $\begin{array}{l}N S \\
* \\
+\end{array}$ & 1211 & p. 274 & & \\
\hline
\end{tabular}

Table 2. Metabolism of $\left[4^{-14} C\right]$ cholesterol, $7 \alpha-\left[6 \beta-{ }^{3} H\right]$ hydroxy-4-cholesten-3-one, $5 \beta-$ $\left[7 \beta-^{3} H\right]$ cholestane- $3 \alpha, 7 \alpha$-diol and $\left[{ }^{3} H\right]$ lithocholic acid in liver homogenates* of rats fed on a semi-synthetic diet containing either glucose or fructose $\dagger$

(Mean values with their standard errors for six rats/group)

\begin{tabular}{|c|c|c|c|c|c|c|}
\hline \multirow[b]{3}{*}{ Substrate } & \multirow[b]{3}{*}{ Reaction } & \multicolumn{4}{|c|}{ Metabolite (nmol/mg protein) } & \multirow{3}{*}{$\begin{array}{c}\text { Statistical } \\
\text { significance } \\
\text { of difference } \\
\text { between } \\
\text { means }\end{array}$} \\
\hline & & \multicolumn{2}{|c|}{ Glucose diet } & \multicolumn{2}{|c|}{ Fructose diet } & \\
\hline & & Mean & SE & Mean & SE & \\
\hline Cholesterol & $7 \alpha$-Hydroxylation & 0.054 & 0.006 & 0.063 & 0.009 & NS \\
\hline $7 \alpha$-Hydroxy-4- & $12 \alpha-$ Hydroxylation & 4.90 & 0.27 & 5.30 & 0.31 & NS \\
\hline cholesten-3-one & $5^{\alpha}$-Reduction & 0.89 & 0.08 & $I \cdot 14$ & 0.14 & NS \\
\hline 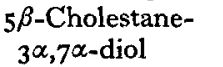 & 26-Hydroxylation & $2 \cdot 8$ & 0.2 & $3 \cdot 4$ & 0.3 & NS \\
\hline Lithocholic acid & $6 \beta$-Hydroxylation & $8 \cdot 8$ & 0.5 & 10.4 & 0.4 & $P<0.05$ \\
\hline & $\begin{array}{l}\text { NS, not significant } \\
* \text { For details of in } \\
+ \text { For details of die }\end{array}$ & e & du & 0 & & \\
\hline
\end{tabular}

cholesten-3-one and $7 \alpha, 12 \alpha$-dihydroxy-4-cholesten-3-one (Danielsson \& Einarsson, I966). The extent of $7 \alpha$-hydroxylation of cholesterol did not differ in glucose, and fructose-fed rats (Table 2 ).

Incubations with $7 \alpha-\left[6 \beta-{ }^{3} H\right]$ hydroxy-4-cholesten-3-one. The main metabolites formed were identified as $7 \alpha, 12 \alpha$-dihydroxy-4-cholesten-3-one, $7 \alpha$-hydroxy-5 $\alpha$-cholestan-3- 
one and $5 \alpha$-cholestane-3 $\beta, 7 \alpha$-diol (Danielsson \& Einarsson, 1966; Björkhem \& Einarsson, 1970). The conversion of $7 \alpha$-hydroxy-4-cholesten-3-one to $7 \alpha, 12 \alpha$-dihydroxy-4-cholesten-3-one was about $15-20 \%$ in the rats given glucose. In these animals the $5^{\alpha}$-reduction (the sum of $7 \alpha$-hydroxy- $5^{\alpha}$-cholestan-3-one and $5^{\alpha-}$ cholestane- $3 \beta, 7 \alpha$-diol) averaged $3-4 \%$. Both the 12 $\alpha$-hydroxylation and the $5 \alpha$ reduction reactions were about equally active in rats fed glucose and fructose (Table 2).

Incubations with $5 \beta$-[7 $\left.\beta-^{3} H\right]$ cholestane- $3 \alpha, 7 \alpha-$ diol. In the glucose-fed rats, about $0.6 \%$ of the material was hydroxylated in the $12 \alpha$-position and $1.6 \%$ was 26 hydroxylated. The metabolites have been identified under the same conditions by Björkhem \& Gustafsson (1973). Compared to glucose-fed rats, the activity of the 26-hydroxylase was about the same in animals given fructose (Table 2).

Incubations with $\left.{ }^{3} \mathrm{H}\right]$ lithocholic acid. The main metabolite formed from lithocholic by the microsomal fraction was $3 \alpha, 6 \beta$-dihydroxy- $5 \beta$-cholanoic acid, as has previously been reported (Einarsson \& Johansson, 1969). The extent of $6 \beta$-hydroxylation was found to be about $16 \%$ in the glucose-fed rats. The activity in the fructose-fed rats was about $20 \%$ higher than that in those given glucose (Table 2).

\section{DISCUSSION}

The bile acids formed from cholesterol in the liver are cholic acid $(3 \alpha, 7 \alpha, 12 \alpha-$

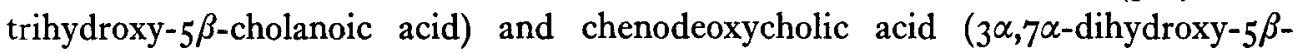
cholanoic acid). During the intestinal passage these bile acids are partially dehydroxylated in the $7 \alpha$-position, cholic acid being transformed to deoxycholic acid, and chenodeoxycholic acid to lithocholic acid. Deoxycholic acid is effectively absorbed from the intestine and rehydroxylated in the rat liver to cholic acid. In this animal both lithocholic acid (which is poorly absorbed) and chenodeoxycholic acid are to a large extent hydroxylated in the $6 \beta$-position (Einarsson \& Johansson, 1969).

Present information indicates the existence of several pathways in the conversion of cholesterol into cholic acid and chenodeoxycholic acid (cf. Danielsson, 1973). The rate-determinating step in the main pathway is the introduction of a $7 \alpha$-hydroxyl group in cholesterol. A key intermediate in subsequent steps is $7 \alpha$-hydroxy-4cholesten-3-one which is further $12 \alpha$-hydroxylated in the biosynthesis of cholic acid. The first step in the degradation of the side chain is a 26-hydroxylation. By this procedure $5 \beta$-cholestane- $3 \alpha, 7 \alpha$-diol is converted to chenodeoxycholic acid, and $5 \beta$-cholestane- $3 \alpha, 7 \alpha, 12 \alpha$-triol is transformed to cholic acid. In another sequence the side chain is oxidized before modification of the steroid molecule. The initial reaction in this pathway, considered to be a minor one, is a 26 -hydroxylation of the cholesterol molecule.

The results of several studies indicate that in vitro studies of bile acid synthesis reflect fairly accurately in vivo conditions. Thus biliary drainage in rats leads to an increased excretion of bile acids and to an increased activity of the $7 \alpha$-hydroxylase in the liver (cf. Björkhem \& Danielsson, I974). In the hyperthyroid rat the normal value for the cholic acid:chenodeoxycholic acid ratio in bile duct bile (about $3: 1$ ) is 
reversed (i.e. about $\mathrm{I}: 3$ ). In keeping with this finding, the results of in vitro studies indicate that the $12 \alpha$-hydroxylation of $7 \alpha$-hydroxy-4-cholesten- 3 -one is decreased in the hyperthyroid rat whereas the 26 -hydroxylation of $5 \beta$-cholestane- $3 \alpha, 7 \alpha$-diol is stimulated (cf. Björkhem \& Danielsson, 1974). Recently Cohen, Raicht, Nicolau \& Mosbach (I975) found that phenobarbital treatment of Sprague-Dawley rats, which produces a decrease in the activity of the $12 \alpha$-hydroxylase in the liver, was associated also with a decrease in the proportion of cholic acid in total biliary bile acids.

As compared to the glucose-fed rats the animals given fructose in the present study had higher serum triglyceride levels. On the basis of previous reports (Eaton \& Kipnis, 1969; Waddell \& Fallon, 1973) it is reasonable to assume that these changes also reflect a higher synthetic rate of both triglycerides and pre- $\beta$-lipoproteins. If so, fructose feeding may produce a metabolic state similar to that found in humans suffering from hyperlipoproteinaemia type IV. This disorder in man, as mentioned previously, is characterized not only by hyperpre- $\beta$-lipoproteinaemia but also by increased bile acid synthesis. However, as suggested by the present study, there is no indication that fructose stimulates bile acid synthesis in the rat. Whether a carbohydrate-induced stimulation of the synthesis of pre- $\beta$-lipoproteins in healthy man is accompanied by increased bile acid formation is not known. If this is the situation, our results indicate that there are species differences. Studies to elucidate this possibility are in progress.

The work was supported by grants from the Swedish Medical Research Council and by grants from Karolinska Institutes Forskningsfonder.

\section{REFERENCES}

Adams, P. W., Kissebah, A. H., Harrigan, P., Stokes, T. \& Wynn, V. (1974). Eur. F. clin. Invest. 4, 149.

Anderson, J. T., Grande, F., Matsumoto, Y. \& Keys, A. (1963). F. Nutr. 79, 349.

Bergström, S. \& Gloor, U. (r955). Acta chem. scand. 9, 34.

Björkhem, I. (1969). Eur, F. Biochem. 8, 337 .

Björkhem, I. \& Danielsson, H. (1974). Mol. Cell. Biochem. 4, 79.

Björkhem, I. \& Einarsson, K. (1970). Eur. F. Biochem. 13, 174.

Björkhem, I. \& Gustafsson, J. (1973). Eur. F. Biochem. 36, 201.

Cohen, R. I., Raicht, R. F., Nicolau, G. \& Mosbach, E. H. (1975). Lipids ro, 168.

Danielsson, H. (1973). In The Bile Acids, vol. 2, p. I [P. P. Nair and D. Kritchevsky, editors]. New York: Plenum Press.

Danielsson, H. \& Einarsson, K. (1966). F. biol. Chem. 241, 1449.

Danielsson, H., Einarsson, K. \& Johansson, G. (1967). Eur. $\mathcal{~ . ~ B i o c h e m . ~ 2 , ~} 44$.

Eaton, R. P. \& Kipnis, D. M. (1969). Am. F. Physiol. 217, i 160.

Einarsson, K. \& Gustafsson, J.-A. (1974). Biochem. Pharmac. 23, 9.

Einarsson, K., Hellström, K. \& Kallner, M. (1974). F. clin. Invest. 54, 130r.

Einarsson, K. \& Johansson, G. (1969). FEBS Lett. 4, 177.

Frederickson, D. S., Levy, R. J. \& Lees, R. S. (1967). New Engl. F. Med. 276, 34, 94, 148, $215,273$.

Hanel, H. K. \& Dam, H. (1955). Acta chem. scand. 9, 677.

Kaufmann, N. A. \& Kapitulnik, J. (1973). Acta med. scand. Suppl. 542, 229.

Laurell, S. (1966). Scand. F. clin. Lab. Invest. 18, 668.

Lowry, O. H., Rosebrough, N. J., Farr, A. L. \& Randall, R. J. (195I). J. biol. Chem. 193, 265.

Macdonald, S. \& Braithwaite, D. M. (r964). Clin. Sci. 27, 23.

Nestel, P. J. (r966). Clin. Sci. 3r, 3 I.

Nikkilä, E. A. \& Kekki, M. (1972). Eur. F. clin. Invest. 2, 23 I. 
Vol. 36

Nikkilä, E. A. \& Ojala, K. (1965). Life Sci. 4, 937.

Quarfordt, S. H., Frank, A., Shames, D. M., Berman, M. \& Steinberg, D. (1970). F. clin. Invest. 49, 228I.

Reaven, G. M., Hill, D. B., Gross, R. C. \& Farquhar, J. W. (1965). F. clin. Invest. 44, 1826.

Schonfeld, G. \& Pfleger, B. (1971). F. Lipid Res. 12, 614.

Waddell, M. \& Fallon, H. J. (1973). F. clin. Invest. 52, 2725.

Wu, C.-H. \& Shreeve, W. W. (1975). Metabolism 24, 755. 